1. MBBS, MCPS, FCPS

Assistant Professor

Department of Medicine

SMBBMC \& LGH Karachi.

2. MBBS, MD

Associate Professor

Department of Medicine

SMBBMC \& LGH Karachi.

3. FCPS, FRCS

Consultant Surgeon

Dr Ruth KM pfau Civil Hospital Karachi.

4. MBBS, MCPS, FCPS

Assistant Professor

Department of Paediatrics

SMBBMC \& LGH Karachi.

5. MBBS, FCPS

Assistant Professor

Department of Psychiatry

DIMS \& DUHS Karachi

6. MBBS, FCPS

Associate Professor

Department of Paediatrics

CHK \& DUHS Karachi

Correspondence Address:

Dr. Nathu Mal

MBBS, MCPS, FCPS

Assistant Professor

Department of Paediatrics

Shaheed Muhtrama Benazir Bhutto

Medical College

Layari General Hospital Karachi,

Sindh, Pakistan.

drnathumal@gmail.com

Article received on:

19/03/2018

Accepted for publication:

09/10/2018

Received after proof reading:

22/05/2019

\section{SERUM FERRITIN AND IRON PROFILE IN HELICOBACTER PYLORI INFECTED YOUNG ADULT MALE REPORTING AT A TERTIARY CARE HOSPITAL.}

\begin{abstract}
Suresh Kumar ${ }^{1}$, Arshad $\mathrm{Ali}^{2}$, Dileep Kumar ${ }^{3}$, Nathu Mal ${ }^{4}$, Urooj Tabassum $^{5}$, Bilawal Hingorjo ${ }^{6}$
ABSTRACT... Determination of serum ferritin and iron profile in Helicobacter pylori infected young adult male reporting at a tertiary care hospital of Sindh. Study Design: Case control study. Setting: Department of Medicine, Layari General Hospital Shaheed Muhtrama Benazir Bhutto Medical College Period: January 2015 to February 2016. Materials and Methods: 100 cases $(H$. pylori stool specific antigen positive) and 100 controls (H pylori negative) were selected and studied. $5 \mathrm{ml}$ blood was collected in a disposable syringe by venesection. $2 \mathrm{ml}$ was put in EDTA tubes and $3 \mathrm{ml}$ was centrifuged (3000 x rpm for 10 minutes). Sera were used for the estimation of iron profile. Elisa assay method (Fortress diagnostics) detected the $\mathrm{H}$. pylori stool specific antigen (HpSA). Data was analyzed on SPSS 22.0 (USA) at 95\% Cl (P $\leq 0.05)$. Results: Age of control and cases was noted $35.48 \pm 4.79$ and $33.60 \pm 3.96$ years $(P=0.053)$. Hb, Hct and $\mathrm{RBC}$ counts were low in cases $(\mathrm{P}=0.0001)$ significantly. Serum iron $(\mathrm{Fe}++)$, ferritin and TIBC in controls and cases were noted 152.72 \pm 6.08 and $118.79 \pm 43.30 \mu \mathrm{g} / \mathrm{dl}, 394.34 \pm 136.50$ and $529.87 \pm 101.0 \mathrm{ng} / \mathrm{dl}$, \& $140.80 \pm 19.99$ and $130.88 \pm 28.46 \mu \mathrm{g} / \mathrm{dl}$ respectively $(P=0.0001)$ (Table-I). Conclusion: Helicobacter pylori infection causes iron malabsorption as detected by serum iron and ferritin and total iron binding capacity in young adult male.
\end{abstract}

Key words: $\quad$ Helicobacter pylori, Ferritin, Iron, TIBC, Male.

Article Citation: Kumar S, Ali A, Kumar D, Mal N, Tabassum U, Hingorjo B. Serum ferritin and iron profile in helicobacter pylori infected young adult male reporting at a tertiary care hospital. Professional Med J 2019; 26(6):896-901.

DOI: 10.29309/TPMJ/2019.26.05.3591

\section{INTRODUCTION}

One of the most important human pathogen of current era is a gram negative bacterium that inhabits the acidic gastric environment; called the Helicobacter pylori (H pylori). It is a gram negative helix shaped microaerophilic bacteria. Currently, it infects $>50 \%$ human population of world. It is capable of survival against the acidic medium of stomach. It colonizes the gastric mucosa. ${ }^{1}$ $\mathrm{H}$. pylori have been implicated in the etiology and pathogenesis of gastric ulcers, gastric carcinomas, gastric lymphoma and atrophic gastritis..$^{2,3}$ Extra gastric disorders have also been linked with $\mathrm{H}$. pylori infection. ${ }^{3} \mathrm{Few}$ of extra- gastric disorders associated with $\mathrm{H}$. pylori infection include the chronic idiopathic thrombocytopenic purpura (CITP), chronic cholecystitis, etc. Iron deficiency anemia (IDA) has been reported in the $\mathrm{H}$. pylori infected patients. Eradication of $\mathrm{H}$. pylori ameliorates the IDA of unknown cause,
CITP, etc. Previous meta- analysis suggested the association of $\mathrm{H}$. pylori infection with depletion of iron stores and its eradication replete the iron store. ${ }^{4,5}$ Further evidence suggests the eradication of $\mathrm{H}$. pylori also replete the blood hemoglobin $(\mathrm{Hb})$ and serum ferritin. ${ }^{6}$ Patients with IDA must be eradicated from the $\mathrm{H}$. pylori eradication, this has been strongly recommended by the Western medical guidelines. ${ }^{3}$ Few reports from other geographical regions of World have negated the association of $\mathrm{H}$. pylori infection and IDA. ${ }^{7}$ Pathological link of $\mathrm{H}$. pylori infection and iron metabolism is not clearly and needs further investigations at the molecular levels for better understanding and planning for the remedy. ${ }^{8,9}$

A few studies reported strong association of $\mathrm{H}$. pylori infection, Iron deficiency and IDA. In Japan, a study reported on the improvement of iron metabolism after $\mathrm{H}$. pylori. ${ }^{9}$ In South East 
Asian countries including Pakistan, majority of population is infected with $\mathrm{H}$. pylori with low gastric acidity and gastric atrophy. Hence the possibility of $\mathrm{H}$. pylori infection with iron malabsorption needs further research. Acid secretion within stomach keeps the gastric mucosa healthy. ${ }^{10}$ However, mechanism of iron malabsorption and deficiency caused by $\mathrm{H}$. pylori infection is not fully understood. ${ }^{10}$ Suggested mechanisms implicated in the pathogenesis of $\mathrm{H}$. pylori induced iron malabsorption are; Iron consumption by $\mathrm{H}$. pylori with expression of iron transporters, ${ }^{11}$ and impairment of iron chelation with lactoferrin. ${ }^{12}$ $H$. pylori utilizes iron and ferritin for growth and proliferation. $^{13}$

With this background, and prevalent $\mathrm{H}$. pylori infection in Pakistan, it needs more research on iron metabolism and serum ferritin. Keeping this scenario of prevalent $\mathrm{H}$. pylori infection in country, the present research analyzed the serum ferritin, iron and total iron binding capacity (TIBC) and serum ferritin levels at our tertiary hospital. The present study hypothesized such relationship does not exist until proved otherwise.

\section{SUBJECTS AND METHODS}

A case control study was designed to analyze the serum ferritin and iron profile in $\mathrm{H}$. pylori infected subjects. Ethical permission was sought from the institution's review committee. Participants for the study purpose were selected from the Department of Medicine, Layari General Hospital Shaheed Muhtrama Benazir Bhutto Medical College from January 2015 to February 2016. A sample of $100 \mathrm{H}$. pylori infected $(\mathrm{H}$. pylori stool specific antigen positive) subjects were labelled as cases and 100 normal healthy subjects $(\mathrm{H}$. pylori negative) were taken as control.

Study participants were selected by nonprobability (purposive) sampling according to strictly exercised criteria of inclusion and exclusion. $\mathrm{H}$. pylori stool specific antigen (HpSAg) positive, young adult male, age 20- 40 years, presenting with gastric dyspeptic symptoms were included. Female subjects and subjects with concomitant systemic disease such as diabetes mellitus, inflammatory bowel disease, chronic diarrhoea, etc were excluded. Control and cases taking betel nuts, pan, gutkha, manipuri, etc were also excluded. Cases and control were interviewed and informed purpose of research study, gain and loss, and merits and demerits. They were free to ask questions about the loss or damage to them if they are thinking of it. They were informed that the charges laboratory investigation will be paid by the researcher. Research will cause no harm to them and will be beneficial to the community against the $\mathrm{H}$. pylori. Over the duration of study, many subjects were examined, interviewed and communicated. Finally, only volunteer participants qualified for the entry into research protocol who gave a signed informed consent. All of volunteers were informed if they have any query or problem, they are free to ask and even can withdraw from the study protocol without telling the reason, and this will not affect their medical therapy. Willing participants were requested to comply with research protocol voluntarily. All volunteers were examined by a medical officer and a consultant physician.

Volunteers were asked for sampling of blood and stool. HpSAg was assayed by Elisa kit (Fortess Diagnostics). A $5 \mathrm{ml}$ disposable syringe was used for blood sampling from ante cubital vein. Area was clean and sterilized by alcohol swab. Of $5 \mathrm{ml}$ blood, $2 \mathrm{ml}$ was put into EDTA tube, remaining $3 \mathrm{ml}$ was centrifuged to separate out sera. Sera were obtained by centrifugation of $3000 \times \mathrm{rpm}$ for 10 minutes. EDTA samples were used for the estimation of hematocrit (Hct), hemoglobin $(\mathrm{Hb})$ and Red blood cell (RBC) counts. Iron profile parameters were estimated from the sera. Serum ferritin was detected by Immulite immunoassay kit (Chemiluminnescent system, UK). Rang of assay kit was 7- $149 \mathrm{ng} / \mathrm{ml}$. Biochemical estimation of parameters was conducted on the Cobas e 411 analyzer (Roche Diagnosis $\mathrm{GmbH}$, Mannheim, Germany). Data was noted in a predesigned pre structured proforma. Confidentiality was maintained and signing of consent form by volunteers was mandatory. All data variables were analyzed on SPSS 22.0 (USA). Statistical comparisons of continuous variables was performed by the Student's t-test (Independent samples). Data analyzed at $95 \%$ Confidence 
interval $(P \leq 0.05)$.

\section{RESULTS}

Age (mean \pm SD) of control and cases was noted $35.48 \pm 4.79$ and $33.60 \pm 3.96$ years $(P=0.053)$. $\mathrm{Hb}$, Hct and RBC counts were found significantly low in cases $(P=0.0001)$ (Table-l). Serum iron $(\mathrm{Fe}++)$, ferritin and TIBC in controls and cases were noted $152.72 \pm 6.08$ and $118.79 \pm 43.30$ $\mu \mathrm{g} / \mathrm{dl}, 394.34 \pm 136.50$ and $529.87 \pm 101.0 \mathrm{ng} /$ $\mathrm{dl}, \quad \& 140.80 \pm 19.99$ and $130.88 \pm 28.46 \mu \mathrm{g} / \mathrm{dl}$ respectively $(\mathrm{P}=0.0001)$ (Table-l). Serum iron is shown in Figure-1, serum TIBC in Figure-2 and serum ferritin levels in Figure-3.

\section{DISCUSSION}

The present observed low serum ferritin and serum iron in young male with H.pylori infection (H. pylori stool specific antigen positive). It is first study which reports on the serum iron profile in young adult male with active $\mathrm{H}$. pylori infection.

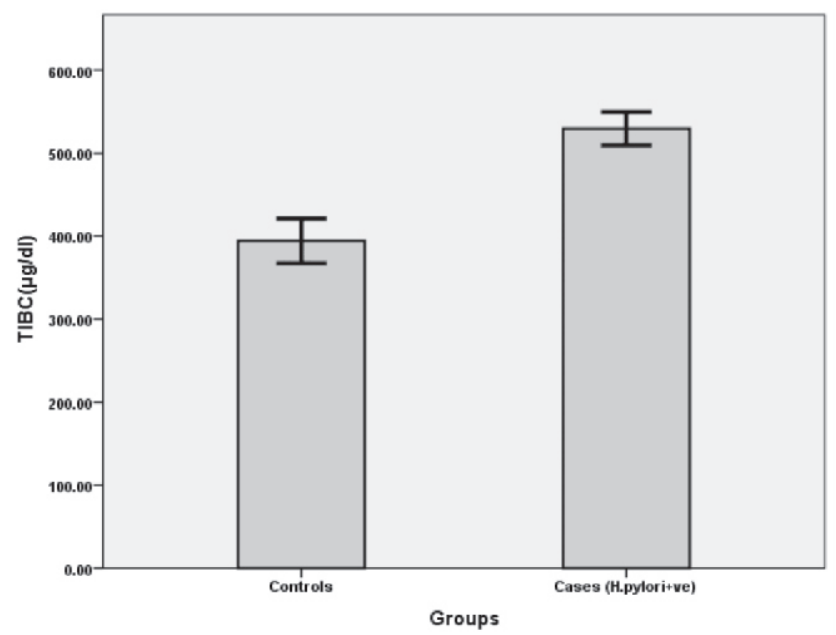

Figure-2. Serum TIBC levels in controls and cases
Age (mean \pm SD) of control and cases was noted $35.48 \pm 4.79$ and $33.60 \pm 3.96$ years $(P=0.053)$, this shows the study included young population.

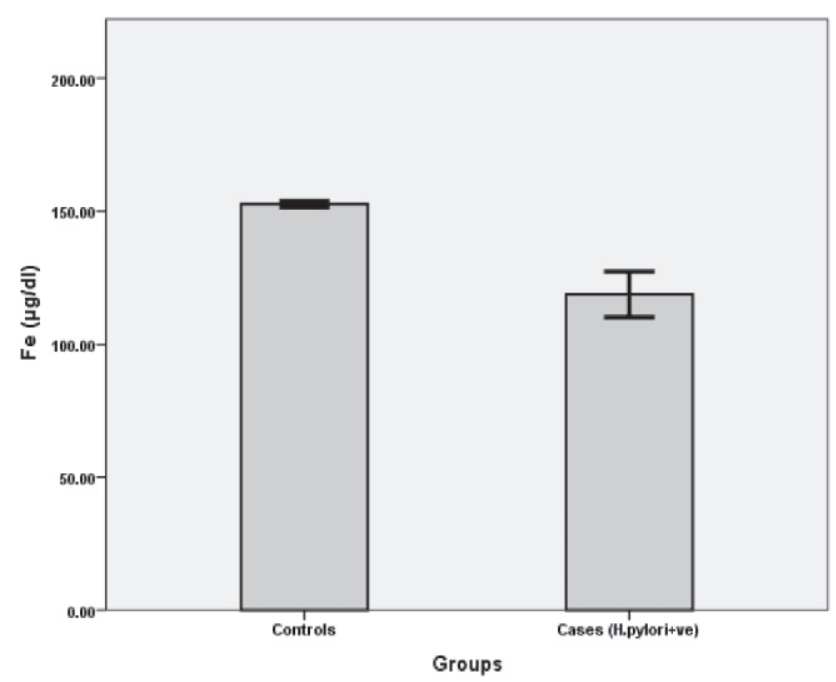

Figure-1. Serum iron levels in controls and cases

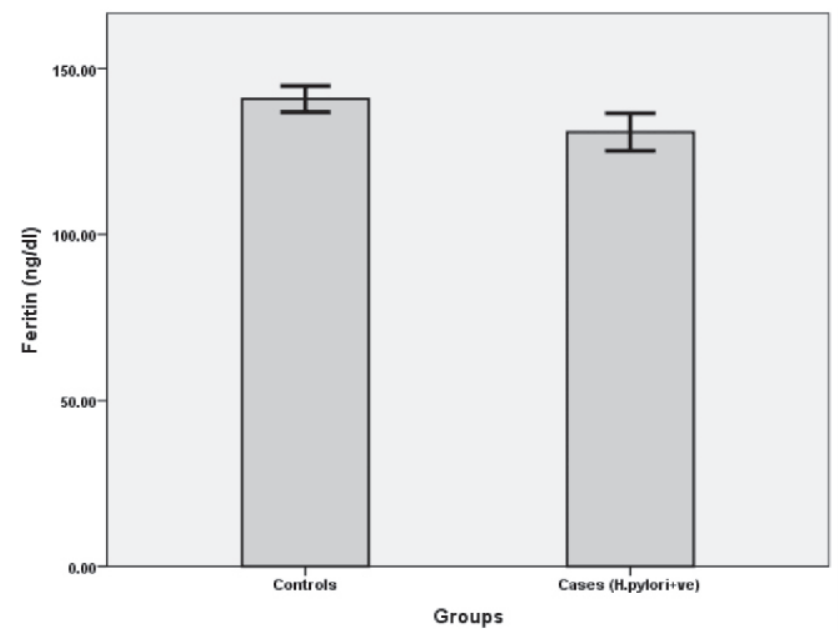

Figure-3. Serum ferritin levels in controls and cases

\begin{tabular}{|l|c|c|c|}
\hline & $\begin{array}{c}\text { Control } \\
\text { (H.pylori -ve) }\end{array}$ & $\begin{array}{c}\text { Cases } \\
\text { (H.pylori +ve) }\end{array}$ & P-value \\
\hline Age (years) & $35.48 \pm 4.79$ & $33.60 \pm 3.96$ & 0.053 \\
\hline Hemoglobin $(\mathrm{g} / \mathrm{dl})$ & $13.15 \pm 2.49$ & $11.81 \pm 4.62$ & 0.0001 \\
\hline Hematocrit $(\%)$ & $41.92 \pm 5.26$ & $35.95 \pm 9.40$ & 0.0001 \\
\hline RBC counts $\left(\mathrm{x} 10^{6} / \mu \mathrm{L}\right)$ & $4.25 \pm 0.22$ & $3.95 \pm 0.49$ & 0.0001 \\
\hline Serum Fe++ $(\mu \mathrm{g} / \mathrm{dl})$ & $152.72 \pm 6.08$ & $118.79 \pm 43.30$ & 0.0001 \\
\hline Serum Ferritin $(\mathrm{ng} / \mathrm{dl})$ & $394.34 \pm 136.50$ & $529.87 \pm 101.0$ & 0.0001 \\
\hline Serum TIBC $(\mu \mathrm{g} / \mathrm{dl})$ & $140.80 \pm 19.99$ & $130.88 \pm 28.46$ & 0.005 \\
\hline
\end{tabular}

Table-I. Demography, physical and laboratory findings of study subjects $(n=200)$ 
The findings are in agreement with previous studies. ${ }^{14,15}$ We observed low Hb, Hct, RBC counts, serum $\mathrm{Fe}++$, serum TIBC and serum ferritin levels in H.pylori infected male (cases) compared to controls $(P=0.0001)$. The findings are supported by previous studies. ${ }^{16,17}$

More than $50 \%$ of World population is suffering from $\mathrm{H}$. pylori infection this is true for developing countries like Pakistan. In developing countries, iron deficiency is an established public health problem and this is compounded by the $\mathrm{H}$. pylori infection. ${ }^{18} \mathrm{H}$. pylori is suggested risk factor of iron deficiency, hypoferritinemia and iron deficiency anemia, ${ }^{19}$ this is in keeping with the present study. We found low serum iron $(\mathrm{Fe}++)$ and ferritin and high TIBC. RBC counts, hemoglobin and hematocrit were also found low in cases with active $\mathrm{H}$. pylori infection. In present study, serum iron $(\mathrm{Fe}++)$, ferritin and TIBC in controls and cases were noted 152.72 \pm 6.08 and $118.79 \pm 43.30 \mu \mathrm{g} / \mathrm{dl}, 394.34 \pm 136.50$ and $529.87 \pm 101.0 \mathrm{ng} / \mathrm{dl}, \quad \& 140.80 \pm 19.99$ and $130.88 \pm 28.46 \mu \mathrm{g} / \mathrm{dl}$ respectively $(\mathrm{P}=0.0001)$.

These observations show the $\mathrm{H}$. pylori infection is associated with iron deficiency. HpSAg positive indicates the active $\mathrm{H}$. pylori infection. Our these findings are supported by previous studies. ${ }^{20-22}$ Reports ${ }^{20-22}$ from developing countries have suggested the active $\mathrm{H}$. pylori infection is associated with iron deficiency. Because of many reasons the developing countries have high prevalence of $\mathrm{H}$. pylori infection. Surely, this occurs because of overcrowding, fecal water contamination, poor sanitation, poverty, unhygienic feeding, contaminated foods, and life style habits. ${ }^{22,16,17}$ Serum ferritin is a iron storing protein that is stored source of iron as well as circulates in the blood plasma. Serum ferritin is a reliable biological marker of iron stores of human body. ${ }^{23} \mathrm{~A}$ fallacy of serum ferritin is that it is acute phase protein, so during infections and inflammatory processes, its circulation levels are unreliable. ${ }^{24}$ Low serum ferritin and iron and raised TIBC were observed and this has been attributed to $\mathrm{H}$. pylori infection that disturbs the gastric $\mathrm{pH}$. Resulting hypochlorhydria adversely affects the iron absorption. H. pylori infection causes gastric atrophy and parietal cell damage..$^{25}$ Our findings of low serum ferritin and iron are supported by previous studies. ${ }^{16,17}$ However, other studies 26,27 had reported controversial results of no association of $\mathrm{H}$. pylori infection with iron deficiency. These findings are inconsistent to present and previous studies. ${ }^{16,17,22-25}$

Controversial results may be due to various reasons such as the different study population and geographical areas, life style, dietary habits, food fortification, hygienic conditions, sample size, sampling errors, laboratory errors, statistical errors, etc. We conclude that the $\mathrm{H}$. pylori infection is associated with iron malabsorption; the underlying molecular mechanisms need to be elucidated. The present study has certain limitations such as the; sample size, particular ethnicity, life style, etc that might have affected the results to alternative hypothesis. However, the strength of study lies in its inclusion and exclusion criteria, active $\mathrm{H}$. pylori infection, age matched control, and proper handling of data and statistical analysis.

\section{CONCLUSION}

The present study reports low serum ferritin and serum iron in young male with $\mathrm{H}$. pylori infection. This point to the iron malabsorption induced by $\mathrm{H}$. pylori infection. Eradication of $\mathrm{H}$. pylori infection is recommended for prevention of iron deficiency anemia and related morbidities.

\section{Copyright@ 09 Oct, 2018.}

\section{REFERENCES}

1. Atherton JC and Blaser MJ. Coadaptation of Helicobacter pylori and humans: Ancient history, modern implications. The Journal of Clinical Investigation 2009; 119(9): 2475-2487.

2. Eshraghian A. Epidemiology of Helicobacter pylori infection among the healthy population in Iran and countries of the Eastern Mediterranean Region: A systematic review of prevalence and risk factors. World J Gastroenterol 2014; 20(46): 17618-17625.

3. Malfertheiner P, Megraud F, O'Morain CA, Atherton J, Axon AT, Bazzoli F, et al. The European Helicobacter and microbiota study group. Management of Helicobacter pylori infection-the Maastricht V/ Florence consensus report. Gut 2017; 66: 6-30. 
4. Muhsen K, Cohen D. Helicobacter pylori infection and iron stores: A systematic review and meta-analysis. Helicobacter 2008; 13: 323-340.

5. Qu X H, Huang XL, Xiong P, Zhu CY, Huang YL, Lu LG, et al. Does Helicobacter pylori infection play a role in iron deficiency anemia? A meta-analysis. World $\mathrm{J}$ Gastroenterol 2010; 16: 886-896.

6. Hudak L, Jaraisy A, Haj S, Muhsen K. An updated systematic review and meta-analysis on the association between Helicobacter pylori infection and iron deficiency anemia. Helicobacter 2017; 22(1):1-5.

7. Sandstrom G, Rodjer S, Kaijser B, Borjesson M. Helicobacter pylori antibodies and iron deficiency in female adolescents. PLoS One 2014; 9: e113059.

8. Nakagawa H, Tamura T, Mitsuda Y, Kurata M, Goto Y, et al. Association between Helicobacter pylori infection detected by the 13C-urea breath test and low serum ferritin levels among Japanese adults. Helicobacter 2013; 18: 309-315.

9. Sato $\mathrm{Y}$, Yoneyama O, Azumaya M, Takeuchi M, Sasaki SY, Yokoyama J, et al. The relationship between iron deficiency in patients with Helicobacter pyloriinfected nodular gastritis and the serum prohepcidin level. Helicobacter 2015; 20: 11-18.

10. Sohail S, Hamid S, Anwar I, Khawar S, Qureshi HJ. Vitamin B12, Serum Ferritin and Iron status in patients with and without $\mathbf{H}$. Pylori infection. Pak J Med Health Sci J M H S 2015; 9 (2) 740-3.

11. Choe YH, Oh YJ, Lee NG, Imoto I, Adachi Y, Toyoda N, et al. Lactoferrin sequestration and its contribution to iron-deficiency anemia in helicobacter pyloriinfected gastric mucosa. J Gastroenterol Hepatol 2003; 18(8):980-5.

12. Bineyam Taye, Fikre Enquselassie, Aster Tsegaye, Alemayehu Amberbir, Girmay Medhin, Andrew Fogarty, Karen, et al. Effect of early and current helicobacter pylori infection on the risk of anaemia in 6.5-yearold Ethiopian children. BMC Infectious Diseases 2015; 15:270.

13. Clare Cooksley, Peter J. Jenks, Andrew Green, Alan Cockayne, Robert P. H. Logan and Kim R. Hardie. NapA protects Helicobacter pylori from oxidativestress damage, and its production is influenced by the ferric uptake regulator. Journal of Medical Microbiology 2003; 52:461-9.

14. Mohammed MO. Correlation of endoscopic findings with various helicobacter pylori tests among. International Journal of Clinical Medicine 2014; 5:11808.
15 Ihsan Alsaimary, Maysloon Al- Sadoon, Abdulmohsin Jassim, and Saad Hamadi. Clinical findings and prevalence of helicobacter pylori in patients with gastritis B in Al-Basrah governorate. Oman Med $\mathrm{J}$ 2014; 24(3): 208-211.

16. Soundravally Rajendiran, Bobby Zachariah, Abdoul Hamide. Increased Protein Carbonylation and Decreased Antioxidant Status in Anemic H Pylori Infected Patients: Effect of Treatment. Gastroenterol 2014; 95(159): 110-119.

17. Hamed Said Ali Habib, Hussam Aly Sayed Murad, Elamir Mahmoud Amir, and Taher Fawzy Halawa. Effect of sequential versus standard Helicobacter pylori eradication therapy on the associated iron deficiency anemia in children. Indian J Pharmacol. 2013; 45(5): 470-473.

18. Nakagawa $S$, Shimoyama T, Sato $S$, Chinda D, Nakaji $S$, Fukuda S. Decreased iron stores in patients with Helicobacter pylori infection is improved by eradication without corresponding changes in the intake of iron and vitamin C. Cogent Medicine 2018; 5: 1432539.

19. Ali Zamani, Mamak Shariat, Zohreh Oloomi Yazdi, Shahla Bahremand, Parvin Akbari Asbagh, Afshin Dejakam. Relationship between Helicobacter pylori infection and Serum Ferritin level in primary school children of Tehran-Iran. J Pak Med Assoc 2011; 61:658.

20. Mohammed MO. Correlation of endoscopic findings with various helicobacter pylori tests among. International Journal of Clinical Medicine 2014; 5:11808.

21. Ihsan Alsaimary, Maysloon Al- Sadoon, Abdulmohsin Jassim, and Saad Hamadi. Clinical findings and prevalence of helicobacter pylori in patients with gastritis $\mathrm{B}$ in Al-Basrah governorate. Oman Med J 2014; 24(3): 208-211.

22. Thankachan P, Muthayya S, Sierksma A, Eilander A, Thomas T, Duchateau GS, Frenken LG, Kurpad AV. Helicobacter pylori infection does not influence the efficacy of iron and vitamin $B(12)$ fortification in marginally nourished Indian children. Eur J Clin Nutr 2010 (10):1101-7.

23. Ahad Eshraghian. Epidemiology of Helicobacter pylori infection among the healthy population in Iran and countries of the Eastern Mediterranean Region: A systematic review of prevalence and risk factors. World J Gastroenterol 2014; 20(46): 17618-17625.

24. Hsiang-Yao Shih, Fu-Chen Kuo, Sophie S. W. Wang, Yi-Chang Liu, Meng-Chieh Wu, Yang-Pei, et al. Helicobacter pylori infection and anemia in taiwanese adults. Gastroenterology Research and Practice 2013; 2(1):211-215. 
25. Anoar KA. Relationship of helicobacter pylori infection and serum ferritin level. Int $\mathrm{J}$ Med Res Prof 2016, 2(2); 15-20.

26. Jamieson JA, Kuhnlein HV. The paradox of anemia with high meat intake: A review of the multifactorial etiology of anemia in the Inuit of North America. Nutrition Etiology Reviews 2008; 66: 5. 256-271.
27. Windle HJ, Kelleher D, Crabtree JE. Childhood Helicobacter pylori infection and growth impairment in developing countries: A vicious cycle? Pediatrics 2007; 119: E754-759.

\begin{tabular}{|c|c|c|c|}
\hline \multicolumn{4}{|c|}{ AUTHORSHIP AND CONTRIBUTION DECLARATION } \\
\hline Sr. \# & Author-s Full Name & Contribution to the paper & Author $=$ s Signature \\
\hline 1 & Suresh Kumar & $\begin{array}{l}\text { Literature review, Method } \\
\text { writing. }\end{array}$ & \\
\hline 2 & Arshad Ali & $\begin{array}{l}\text { Literature review, Material static } \\
\text { analysis. }\end{array}$ & \\
\hline 3 & Dileep Kumar & $\begin{array}{l}\text { Concept introduction, Lab. } \\
\text { Investigation. }\end{array}$ & \\
\hline 4 & Nathu Mal & Manuscript, Hand up material. & \\
\hline 5 & Urooj Tabassum & Material hand up proof reading. & \\
\hline 6 & Bilawal Hingorjo & Material hand up proof reading. & \\
\hline
\end{tabular}

